\title{
Estabilidad de la capa de hidroxizincato cálcico formada en las armaduras galvanizadas ante un posterior aumento del valor del $\mathrm{pH}$
}

\author{
Stability of the calcium hydroxyzincate protective \\ layer developed on galvanized reinforcements \\ after a further increase of the $\mathrm{pH}$ value
}

A. MACIAS Y C. ANDRADE IETcc/CSIC Madrid (España)

\section{RESUMEN}

En trabajos anteriores que estudian el comportamiento de armaduras galvanizadas en contacto con medios muy alcalinos que contienen calcio, los autores han señalado la existencia de un umbral de $p H=13,3 \pm 0,1$ por debajo del cual el $\mathrm{Zn}$ en contacto con tales medios se pasiva por formación de una capa continua de hidroxizincato cálcico, mientras que para valores de $\mathrm{pH}$ superiores se corroe continuamente hasta su total desaparición.

Establecer la estabilidad del recubrimiento protector de hidroxizincato cálcico a un aumento de $\mathrm{pH}$ a valores muy alcalinos posterior a su formación, es el objetivo del presente artículo.

Como resultado de las investigaciones realizadas ha podido concluirse que si el recubrimiento de hidroxizincato cálcico se ha desarrollado perfectamente, un posterior incremento del $\mathrm{pH}$ del medio no afecta su estabilidad.

\section{SUMMARY}

In previous works on galvanized reinforcements in contact with $\mathrm{Ca}$ - containing highly alkaline media, the authors have reported the existence of a threshold $\mathrm{pH}$ of $13,3 \pm 0,1$, below which the $\mathrm{Zn}$ in contact with such a medium is passivated by formation of a continuous layer of calcium hydroxyzincate, but at $\mathrm{pH}$ values above this it corrodes continuously until it totally disappears.

The investigation on the stability of the calcium hydroxyzincate layer after an increase of the $\mathrm{pH}$ to very high alkaline values, is the aim of the present paper.

It has been establised that if the calcium hydroxyzincate is perfectly developed, a later increase of the $\mathrm{pH}$ does not affect the stability.

\section{INTRODUCCION}

Resultado de la serie de trabajos realizados para comprender el comportamiento del galvanizado en contacto con hormigón fue el establecimiento de un pH límite en 13,3 $\pm 0,1$ por debajo del cual el galvanizado sufría una corrosión tolerable al desarrollarse sobre su superficie una capa compacta y homogénea de hidroxizincato cálcico, $\mathrm{Ca}\left[\mathrm{Zn}(\mathrm{OH})_{3}\right]_{2} 2 \mathrm{H}_{2} \mathrm{O}$, que aisla eficazmente el metal de las disoluciones alcalinas empleadas como soluciones de simulación del electrolito acuoso encerrado en los poros del hormigón (1) (2) (3) (4) (5). Por encima de este pH límite de $13,3 \pm 0,1$, la velocidad de corrosión es tan alta y la cantidad de ion $\mathrm{Ca}^{2+}$ en disolución tan baja que los cristales de hidroxizincato cálcico crecen aislados no siendo capaces de proteger eficazmente el metal.

\section{INTRODUCTION}

Within the serie of experiments carried out for us in order to know the behaviour of galvanized steel in solutions which simulate the pore concrete solution, the processes of corrosion and passivation of this material are being published (1) (2) (3) (4) (5). As result of these experiments has been the knowledge of the existence of a pH threshold of 13,3 $\pm 0,1$ below which the galvanized suffers a tolerable corrosion developping a layer of corrosion products of calcium hydroxyzincate crystals $\mathrm{Ca}\left[\mathrm{Zn}_{2}(\mathrm{OH})_{6}\right] .2 \mathrm{H}_{2}$ which isolate the metal from the medium. Above this threshold the corrosion rate is so high and the amounts of $\mathrm{Ca}^{2+}$ ions in the solutions so low that the calcium hydroxyzincate crystals grow isolately. The number of these crystals is too low to be able to protect the metal. 
Se comprobó un comportamiento particularmente bueno cuando se adicionan sulfatos alcalinos a la disolución matriz de $\mathrm{Ca}(\mathrm{OH})_{2}$. Los iones sulfato están presentes en el cemento debido al empleo de $\mathrm{CaSO}_{4} \cdot 2 \mathrm{H}_{2} \mathrm{O}$ como regulador de fraguado o debido a la formación de sulfatos alcalinos en el horno de clinkerización fruto de la combinación de los compuestos alcalinos presentes en las materias primas del cemento y el azufre del combustible.

Cuando los iones sulfato están presentes, el $\mathrm{pH}$ de la fase acuosa se mantiene siempre por debajo del umbral de 13,3 antes mencionado, y ello debido a la formación y precipitación de $\mathrm{CaSO}_{4}$. Un aumento de $\mathrm{pH}$ hacía valores más alcalinos se produce sólo cuando los iones $\mathrm{SO}_{4}=$ desaparecen de la disolución al precipitar por reacción con los aluminatos.

La estabilidad de la capa de hidroxizincato ante este aumento posterior del $\mathrm{pH}$ del medio, es el problema abordado en el presente trabajo.

Para estudiar la posible disolución de la capa protectora de hidroxizincato cálcico, distintas cantidades de $\mathrm{KOH}$ o $\mathrm{NaOH}$ fueron adicionadas una vez las barras galvanizadas fueron pasivadas previamente en la disolución saturada de $\mathrm{Ca}(\mathrm{OH})_{2}(\mathrm{pH}=12,6)$, en la disolución $\mathrm{Ca}(\mathrm{OH})_{2}$ sat $+0,1 \mathrm{MKOH}$ $(\mathrm{pH}=13,05)$ o en la disolución $\mathrm{Ca}(\mathrm{OH})_{2}$ sar $+0,2 \mathrm{MKOH}(\mathrm{pH}=13,25)$. $\mathrm{El} \mathrm{pH}$ final es en todos los casos superior al umbral. No se han encontrado en la bibliografía consultada referencias previas en torno a este tema particular.

\section{PARTE EXPERIMENTAL}

\section{Materiales}

Se utilizaron redondos corrugados de $6 \mathrm{~mm}$ de diámetro nominal y $8 \mathrm{~cm}$ de longitud. Los redondos se galvanizaron por inmersión en caliente a $450^{\circ} \mathrm{C}$ hasta obtener un recubrimiento galvanizado de $60-80 \mu \mathrm{m}$ de espesor. El área expuesta al ataque fue de $6,45 \mathrm{~cm}^{2}$.

La composición inicial y final y los valores de $\mathrm{pH}$ de las disoluciones ensayadas se presentan en la tabla I. Los redondos fueron previamente sumergidos por un período superior a siete días en disolución saturada de $\mathrm{Ca}(\mathrm{OH})_{2}$ o en disoluciones saturadas de $\mathrm{Ca}(\mathrm{OH})_{2}$ con adición de $\mathrm{KOH}$ de $\mathrm{pH}$ inferior a $13,3 \pm 0.1$, para ser pasivados. Cuando se alcanzaron velocidades de corrosión suficientemente bajas, nuevas cantidades de $\mathrm{KOH}$ ó $\mathrm{NaOH}$ fueron adicionadas a fin de aumentar el pH de la disolución.
A particular and favourable behaviour was detected when alkaline sulfates are added to the "mother" solution of $\mathrm{Ca}(\mathrm{OH})_{2}$ saturated solution. The sulfate ions are present in the cement due to the use of $\mathrm{CaSO}_{4} .2 \mathrm{H}_{2} \mathrm{O}$ as setting regulator or because alkaline sulfates are formed in the kiln from the cement raw materials and the sulphur of the combustible.

Owing to the formation and precipitation of the $\mathrm{CaSO}_{4}$, when sulfates are present the $\mathrm{pH}$ value of the pore solution is always maintained below the threshold of 13,3. Only when sulfates disappears from the solution because of the reaction with the aluminates, the $\mathrm{pH}$ value rises to more alkaline levels.

The investigation on the stability of the calcium hydroxyzincate layer after this increase of the $\mathrm{pH}$ to very high alkaline values is the aim of the present paper. To study if the protective layer of $\mathrm{Ca}\left[\mathrm{Zn}_{2}(\mathrm{OH})_{6}\right] .2 \mathrm{H}_{2} \mathrm{O}$ is dissolved, different amounts of $\mathrm{KOH}$ or $\mathrm{NaOH}$ were added after the bars were previously passivated in the $\mathrm{Ca}(\mathrm{OH})_{2}$ saturated solution $(p H=12,6)$, in the $\mathrm{Ca}(\mathrm{OH})$, sat. $+0,1 \mathrm{M} \mathrm{KOH}$ solution $(\mathrm{pH}=13,05)$ or in the $\mathrm{Ca}(\mathrm{OH})_{2}$ sat + $+0,2 \mathrm{MKOH}$ solution $(\mathrm{pH}=13,25)$. The final $\mathrm{pH}$ values resulted above the $\mathrm{pH}$ threshold. No previous references were found in the literature about this particular subject.

\section{EXPERIMENTAL}

\section{Materials}

Reinforcing corrugated $6 \mathrm{~mm}$ nominal diameter and $8 \mathrm{~cm}$ long steel bars, having a 60-80 $\mu \mathrm{m}$ coating, produced by hot dip galvanizing at $450^{\circ} \mathrm{C}$ were used. The exposed area was $6,45 \mathrm{~cm}^{2}$.

The initial and final composition and the $\mathrm{pH}$ values of the solution tested are given in the table I. The bars were first inmmersed for more than seven days in saturated solutions of $\mathrm{Ca}(\mathrm{OH})_{2}$ or of $\mathrm{Ca}(\mathrm{OH})_{2}+\mathrm{KOH}$. The $\mathrm{pH}$ values were lower than 13,3 $\pm 0,1$ in order to be passivated. When very low corrosion rates are reached, new amounts of $\mathrm{KOH}$ or $\mathrm{NaOH}$ were added to rise the $\mathrm{pH}$ of the solution. 
TABLA I

Composición inicial y final y $\mathrm{pH}$ de las disoluciones ensayadas Initial and final composition and $\mathrm{pH}$ of the solutions tested

\begin{tabular}{|c|c|c|c|c|c|c|c|}
\hline \multirow{2}{*}{$\begin{array}{c}\text { CELL } \\
\text { CELULA }\end{array}$} & \multicolumn{2}{|c|}{ INITIAL COMPOSITION } & \multirow{2}{*}{$\begin{array}{l}\text { INITIAL } \\
\text { pH VALUE }\end{array}$} & \multicolumn{3}{|c|}{ FINAL COMPOSITION } & \multirow{2}{*}{$\begin{array}{r}\text { FINAL } \\
\text { pH VALUE }\end{array}$} \\
\hline & $\mathrm{Ca}(\mathrm{OH})_{2}$ & КОн (M) & & $\mathrm{Ca}(\mathrm{OH})_{2}$ & KOH (M) & $\mathrm{NaOH}(\mathrm{M})$ & \\
\hline 1 & sat & - & 12,63 & sat & 0,2 & - & 13,20 \\
\hline 2 & sat & - & 12,65 & sat & 0,25 & - & 13,31 \\
\hline 3 & sat & - & 13,66 & sat & 0,3 & - & 13,39 \\
\hline 4 & sat & - & 12,68 & sat & 0,5 & - & 13,45 \\
\hline 5 & sat & - & 12,64 & sat & 1 & - & 13,86 \\
\hline 6 & sat & - & 12,66 & sat & - & 0,5 & 13,31 \\
\hline 7 & sat & 0,1 & 12,67 & sat & 0,2 & 0,2 & 13,27 \\
\hline 8 & sat & 0,1 & 13,04 & sat & 0,25 & - & 13,31 \\
\hline 9 & sat & 0,2 & 13,07 & sat & 0,3 & - & 13,45 \\
\hline 10 & sat & & - & sat & 0,4 & - & - \\
\hline
\end{tabular}

La célula de corrosión ha sido descrita en trabajos previos (8). Las células fueron conservadas a $25 \pm 1^{\circ} \mathrm{C}$ por un período total de inmersión de 33 días. En el caso de la célula $\left[\mathrm{Ca}(\mathrm{OH})_{2} \text { sat }+0,2 \mathrm{MKOH}\right]_{20 \text { dias }}+$ $+0,2 \mathrm{MKOH}$ el período de ensayo fue de 180 días.

\section{Técnicas}

La intensidad de corrosión, $i_{\text {corr }}$, fue estimada como en trabajos previos (8) a partir de la resistencia de polarización empleando la fórmula de Stern y Geary (9):
The corrosion cell has been described in previous works (8). The cells were kept at $25 \pm 1^{\circ} \mathrm{C}$ for a total immersion period of 33 days. In case of the cell [sat. sol. $\mathrm{Ca}(\mathrm{OH})_{2}+$ $+0,2 \mathrm{M} \mathrm{KOH}]_{20 \text { days }}+0,2 \mathrm{M} \mathrm{KOH}$, the test period was 180 days.

\section{Techniques}

The corrosion intensity, $i_{\text {corr }}$, was estimated in the same way than in previous works (8) from the polarization resistance using the formula of Stern and Geary (9):

$$
i_{\text {corr }}=\frac{\beta_{\mathrm{a}} \beta_{\mathrm{c}}}{2,3\left(\beta_{\mathrm{a}}+\beta_{\mathrm{c}}\right) R_{\mathrm{p}}}=\frac{B}{R_{\mathrm{p}}}
$$

Los valores de $B$ usados durante el período de pasivación fueron: $6 \mathrm{mV}$ cuando los redondos exhíbian una alta intensidad de corrosión y uno de $52 \mathrm{mV}$ a partir del momento de su pasivación. Después de la adición de álcali se utilizó un valor de $26 \mathrm{mV}$ en todas las células, con la excepción de la célula en la que se adicionó $1 \mathrm{M}$ en $\mathrm{KOH}$, caso en que después de la adición se empleó un valor de $B=6 \mathrm{mV}$. Los valores de $B$ utilizados se eligieron por ser aquellos que conducian a una buena concordancia entre las pérdidas de peso gravimétricas y las electroquímicas.

El $\mathrm{pH}$ fue medido con un $\mathrm{pH}$ metro digital marca ORION modelo DIGIT 501 y un electrodo de rango 0-14. El pH metro fue calibrado usando dos tampones Merk: uno de $\mathrm{pH}=7$ y otro de $\mathrm{pH}=12$ ó 13 dependiendo del valor esperado de $\mathrm{pH}$ de la disolución problema.
During the passivation period the values of constant $B$ used were: $6 \mathrm{mV}$ during the period of high corrosion rates and $52 \mathrm{mV}$ when they become passivated. After the addition of alkali a value of $26 \mathrm{mV}$ was used in all the cells except the cell with an addition of $1 \mathrm{M} \mathrm{KOH}$ where a value of $6 \mathrm{mV}$ after the addition was used. The $B$ values used were those which allow a better agreement between gravimetric and alectrochemical weight losses.

The $\mathrm{pH}$ was measured with an ionanaliser microprocesor "Orion" Model 901 and a combined electrode for the $\mathrm{pH}$ range $0-14$. The $\mathrm{pH}$-meter was calibrated using two Merck buffers: one of $\mathrm{pH}=7$ and other whose $\mathrm{pH}$ was 12 or 13 depending of the $\mathrm{pH}$ value expected. 


\section{RESULTADOS}

Los cambios en la intensidad y potencial de corrosión de los redondos galvanizados sumergidos en las células que contenían inicialmente una disolución saturada de $\mathrm{Ca}(\mathrm{OH})_{2}$ y a las que se adicionaron cantidades crecientes de $\mathrm{KOH}$ o $\mathrm{NaOH}$ a los doce dias del comienzo de los ensayos, se presentan en las figuras 1 y 2 . Inmediatamente después de la adición de álcali la intensidad de corrosión aumenta ligeramente si la concentración de álcali añadida es baja, efecto tanto más acusado cuanto mayor es esta concentración de álcali añadida, llegando a alcanzar un orden de magnitud, si la adición es en concentración $1 \mathrm{M}$. Simultáneamente el potencial se mueve hacia valores más negativos.

\section{RESULTS}

The changes in the corrosion intensity and corrosion potential of galvanized bars immersed in cells which contain at the begining only saturatd solution of $\mathrm{Ca}(\mathrm{OH})_{2}$ and to which increasing amounts of $\mathrm{KOH}$ or $\mathrm{NaOH}$ were added after twelve days, were presented in figures 1 and 2. Just after the alkali was added the corrosion intensity increases slightly if the alkali concentration is low and one order of magnitude if the addition is $1 \mathrm{M}$. Also a simultaneous change of the corrosion potential to more negatives values, is detected.

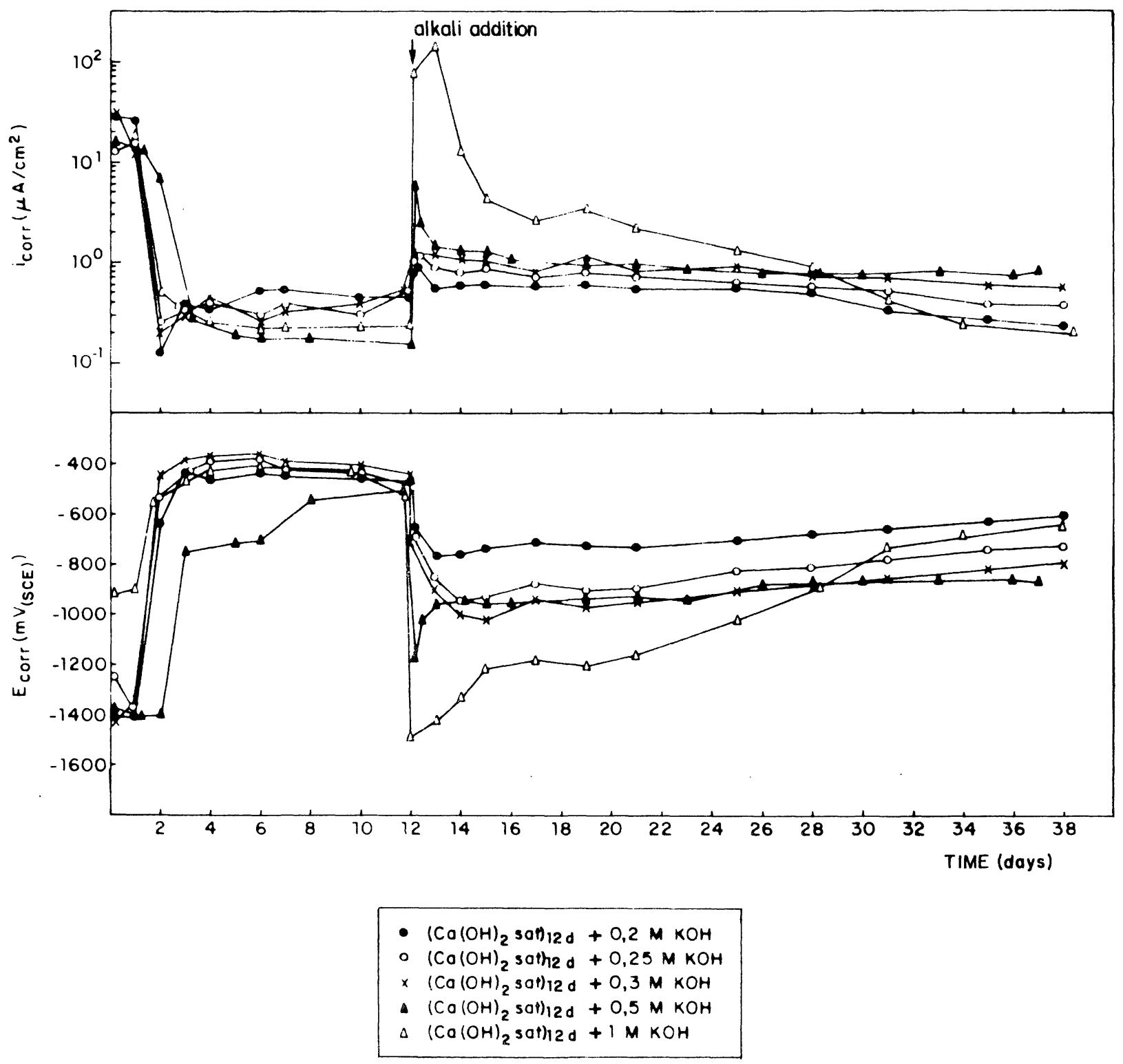

Fig. 1. $-i_{\text {corr }}$ and $E_{c, \text { rr }}$ as a function of time for the solutions $\left[\mathrm{Ca}(\mathrm{OH})_{2}\right.$ sat] $12 \mathrm{~d}+0,2$ to $1 \mathrm{M} \mathrm{KOH}$ tested. 


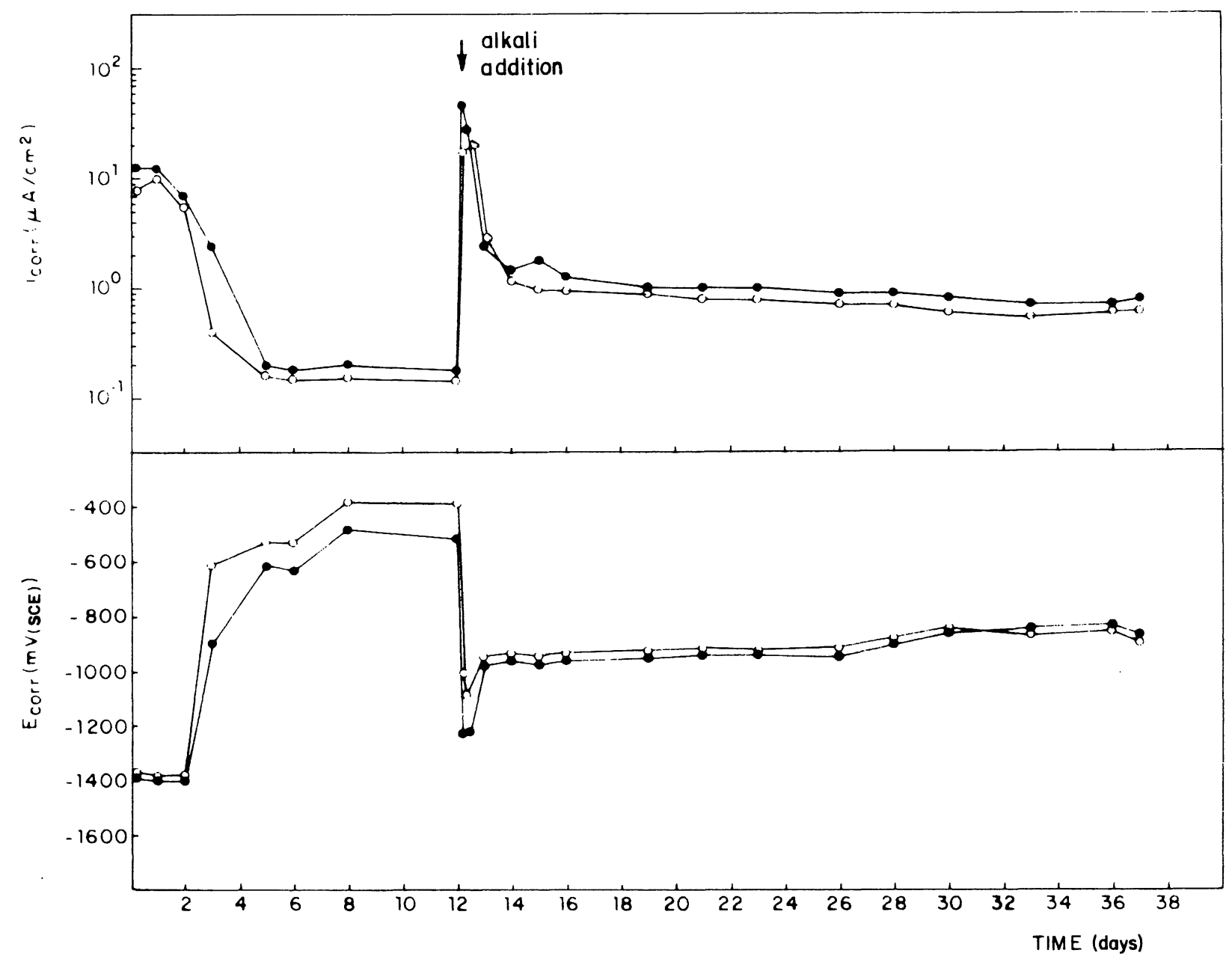

- $\left(\mathrm{CO}(\mathrm{CH})_{2} \mathrm{sat}_{12 \mathrm{~d}}+.5 \mathrm{M} \mathrm{NaCH}\right.$

- $\left(\mathrm{CO}(\mathrm{OH})_{2} \mathrm{SOH}\right)_{12} \mathrm{~d}+0,2 \mathrm{M} \mathrm{KOH}+0,2 \mathrm{M} \mathrm{NaOH}$

Fig. 2. $-i_{\text {corr }}$ and $E_{c, o r r}$ as a function of time for the solutions $\left[\mathrm{Ca}(\mathrm{OH})_{2}\right.$ sat] $12 \mathrm{~d}+0,5 \mathrm{M} \mathrm{NaOH}$ and $\left[\mathrm{Ca}(\mathrm{OH})_{2}\right.$ sat $12 \mathrm{~d}+0,2 \mathrm{M} \mathrm{KOH}+0,2 \mathrm{M} \mathrm{NaOH}$.

Casi inmediatamente -en todos los casos antes de las $24 \mathrm{~h}$, excepto en el caso de una adición $1 \mathrm{M}$ en $\mathrm{KOH}$, en el que tarda al menos 9 días-, las intensidades disminuyen a valores inferiores a $1 \mu \mathrm{A} / \mathrm{cm}^{2}$, mostrando incluso posteriormente una tendencia a la disminución.

El potencial, asimismo se hace menos negativo.

En la figura 3 se recogen los resultados electroquímicos de las células en las cuales los redondos galvanizados fueron pasivados en una disolución $\mathrm{Ca}(\mathrm{OH})_{2}$ sat + $+0,1 \mathrm{M} \mathrm{KOH}(\mathrm{pH}=13,04)$ durante doce dias, tras los cuales se añadieron $0,15(\mathrm{pH}=13,31)$ y $0,2 \mathrm{M} \mathrm{KOH}(13,45)$. En estos casos la variación en intensidad en el momento de la adición es muy pequeña y rápidamente los
This increase of $i_{\text {corr }}$ devanishes again to values about $1 \mu \mathrm{A} / \mathrm{cm}^{2}$ during the first 24 hours after the addition except in the case of $1 \mathrm{M} \mathrm{KOH}$ addition, which takes 9 days to reach again the low values of $i_{\text {corr }}$. The simultaneous rise to anodic values of the $E_{\text {corr }}$ can be seen in te figures 1 and 2 .

Figure 3 shows the same variables for the cell in which the galvanized bars were passivated in a saturated solution of $\mathrm{Ca}(\mathrm{OH})_{2}+0,1 \mathrm{M} \mathrm{KOH}$ $(\mathrm{pH}=13,04)$ and amounts of $0,15(\mathrm{pH}=13,35)$ and $0,2 \mathrm{M} \mathrm{KOH}(\mathrm{pH}=13,45)$ were added after twelve days of the test. The increase of the corrosion intensity is very low. The corrosion potential changes more clearly. 


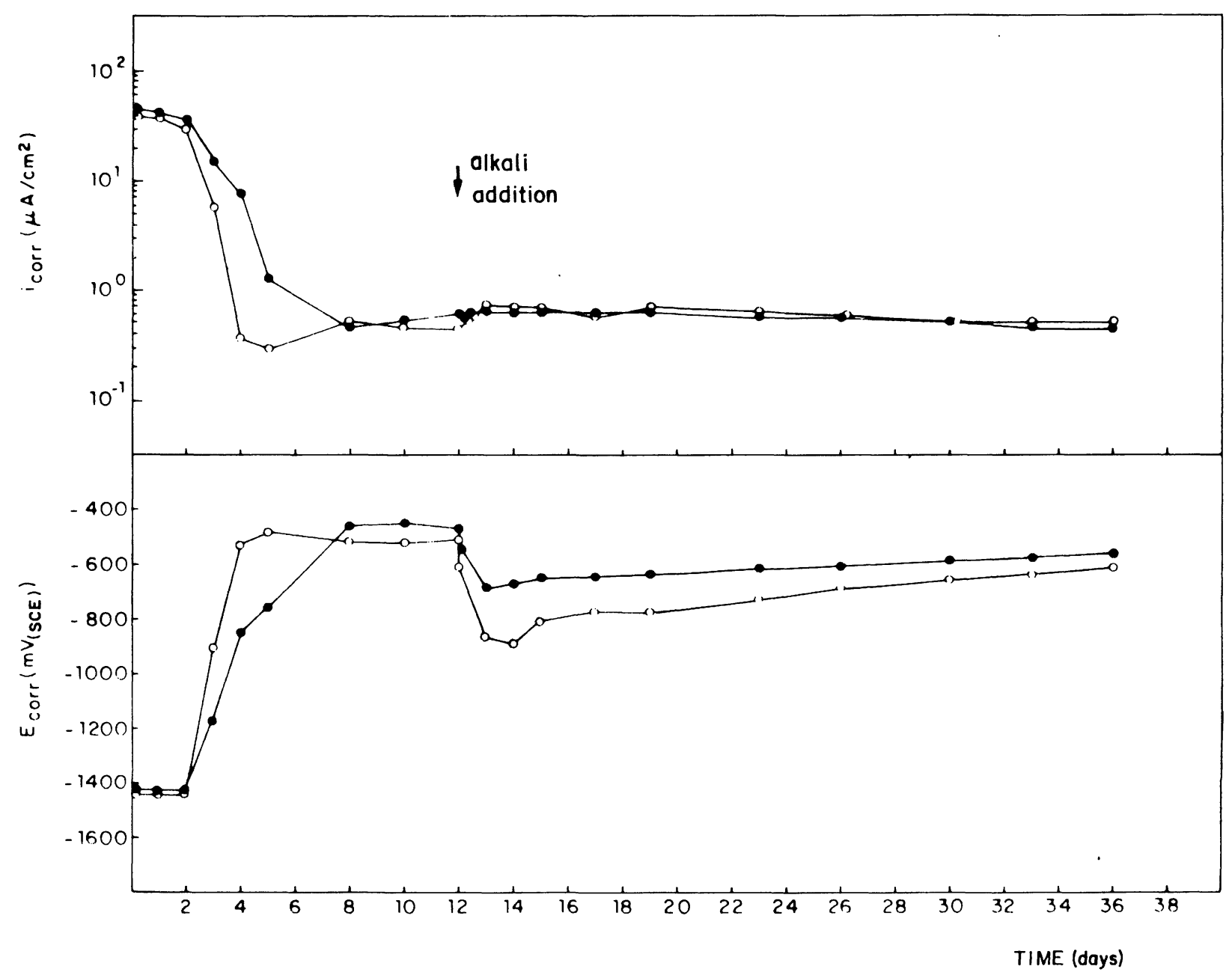

- $\left(\mathrm{CO}(\mathrm{OH})_{2} \text { sot }+0,1 \mathrm{KOH}\right)_{12 \mathrm{~d}}+0,15 \mathrm{KOH}$

- $\left(\mathrm{CO}(\mathrm{OH})_{2} \text { sol }+0,1 \mathrm{KOH}\right)_{12 \mathrm{~d}}+0,2 \mathrm{M} \mathrm{KOH}$

Fig. 3. $-i_{c o r r}$ and $E_{\text {corr }}$ as a function of time for the solutions $\left[\mathrm{Ca}(\mathrm{OH})_{2}\right.$ sat $\left.+0,1 \mathrm{M} \mathrm{KOH}\right] 12 \mathrm{~d}+0,15 \mathrm{M} \mathrm{KOH}$ and $\left[\mathrm{Ca}(\mathrm{OH})_{2}\right.$ sat $\left.+0,1 \mathrm{M} \mathrm{KOH}\right) 12 \mathrm{~d}+0,2 \mathrm{M} \mathrm{KOH}$.

redondos recobran la primitiva velocidad de corrosión. El $E_{\text {corr }}$ acusa más el cambio y presente una mayor inercia a recobrar los valores iniciales.

Dado que la duración de los ensayos presentados en las figuras 1, 2 y 3 fue de 33 días, se llevó a cabo un experimento a 180 días a fin de comprobar si el comportamiento expuesto se mantiene a más largo tiempo.

Los redondos se sumergieron en la disolución de más alta concentración de álcali experimentada que permite la pasivación del galvanizado: $\mathrm{Ca}(\mathrm{OH})_{2}$ sat $+0,2 \mathrm{M} \mathrm{KOH}$ $(\mathrm{pH}=13,25) \mathrm{KOH}$ en concentraciones $0,2 \mathrm{M}$ fue añadida el veinteavo día del ensayo. Los cambios en la intensidad y el potencial de corrosión se muestran en la fig. 4. Es posible comprobar en esta figura como el período de
Because of the tests shown in figures 1,2 and 3 last only 33 days, a 180 days experiment was prepared in order to prove if the behaviour exposed is maintained during longer periods.

The bars were immersed in the solution with the highest concentration in alkali tested which allows passivation of the galvanized:

$\mathrm{Ca}(\mathrm{OH})_{2}$ sat. sol. $+0,2 \mathrm{M} \mathrm{KOH}(\mathrm{pH}=13,2)$.

An amount of $0,2 \mathrm{M} \mathrm{KOH}$ was added the twentieth day of the test. The variation in $i_{\text {corr }}$ and $E_{\text {corr }}$ were shown in figure 4 . It is possible to realise that the passivation period takes longer and the $i_{\text {corr }}$ is higher than in previous 
pasivación es más largo y la $i_{\text {corr }}$ más alta que en figuras previas, como era de esperar dado el valor de $\mathrm{pH}$ de la disolución inicial. Cuando tiene lugar la adición se registra un muy ligero cambio tanto de la $i_{\text {corr }}$ como del $E_{\text {corr }}$. La $i_{\text {corr }}$ alcanza rápidamente los mismos valores que antes de la adición, valores que se mantienen hasta el final del ensayo.

En la figura 5 se han representado las pérdidas de peso gravimétricas frente a las electroquímicas. La buena correlación obtenida confirma que los valores elegidos de la constante $B$ son suficientemente precisos.

Por último se realizó una observación al microscopio electrónico de barrido de la superficie de los redondos una vez extraídos de la disolución para conocer las características de la capa de productos de corrosión formada. Este experimento se llevó a cabo en redondos pasivados durante 28 días en disolución saturada de $\mathrm{Ca}(\mathrm{OH})_{2}$; la concentración de álcali añadida en este caso fue de $0,5 \mathrm{M}$ en $\mathrm{KOH}$.

La apariencia de la superficie de los redondos antes de la adición de $\mathrm{KOH}$ puede observarse en las figuras 6 a y b. El redondo se encontraba totalmente cubierto de una capa de cristales rómbicos de hidroxizincato cálcico compacta. Una hora después de la adición de

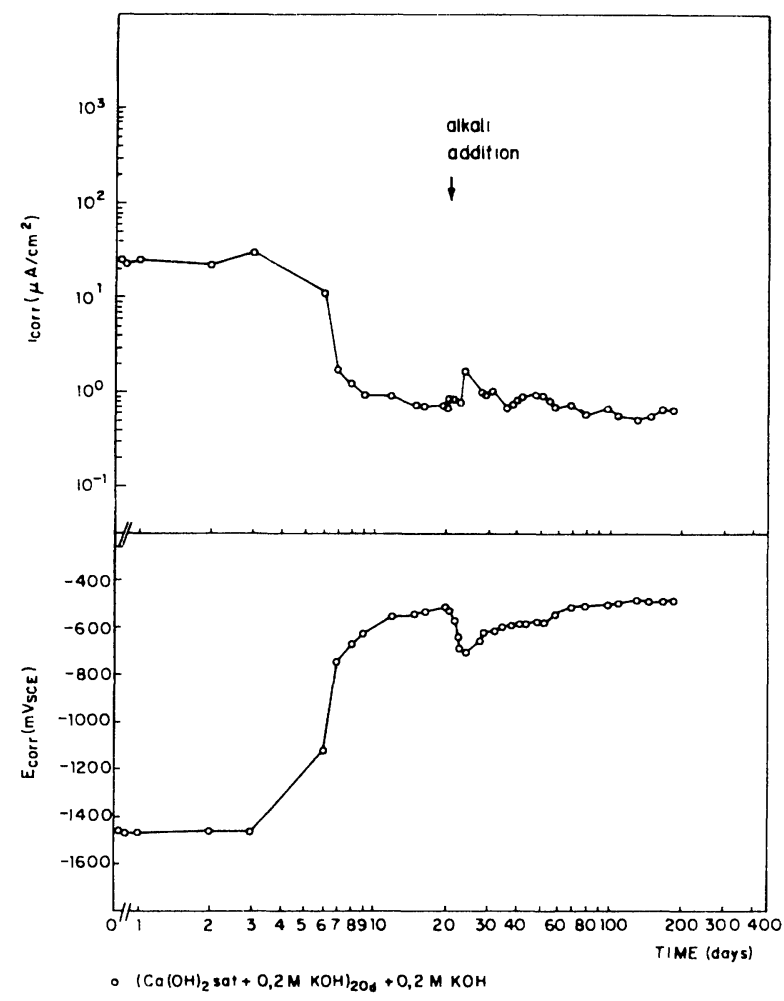

Fig. 4. $-i_{\text {corr }}$ and $E_{\text {corr }}$ as a function of time for the solution $\left[\mathrm{Ca}(\mathrm{OH})_{2}\right.$ sat $\left.+0,2 \mathrm{M} \mathrm{KOH}\right] 20 \mathrm{~d}+0,2 \mathrm{M} \mathrm{KOH}$. figures, as it was expected because of the $\mathrm{pH}$ value of the initial solution. When alkali was added very slight change was recorded. The $i_{\text {corr }}$ values reach very quickly the same values than before the addition. These values remain during the rest of the test.

In figure 5 is represented the agreement between gravimetric and electrochemical weight losses. The good correlation obtained confirms that the values chosen for the constant $B$ are accurate enough.

Finally, SEM observations were made after the bars were extracted from the solutions in order to know the state of the bar surface. This experiment was carried out on bars passivated during 28 days in a sat. sol. of $\mathrm{Ca}(\mathrm{OH})_{2}$. The alkali addition was of $0,5 \mathrm{M} \mathrm{KOH}$.

The aspect of the corrosion product layer before alkali addition is shown in figures 6 a and $b$. The bar was completely covered by rombic crystals of calcium hydroxyzincate. They form a perfect and compact layer. One hour after the addition, crystals of precipitated

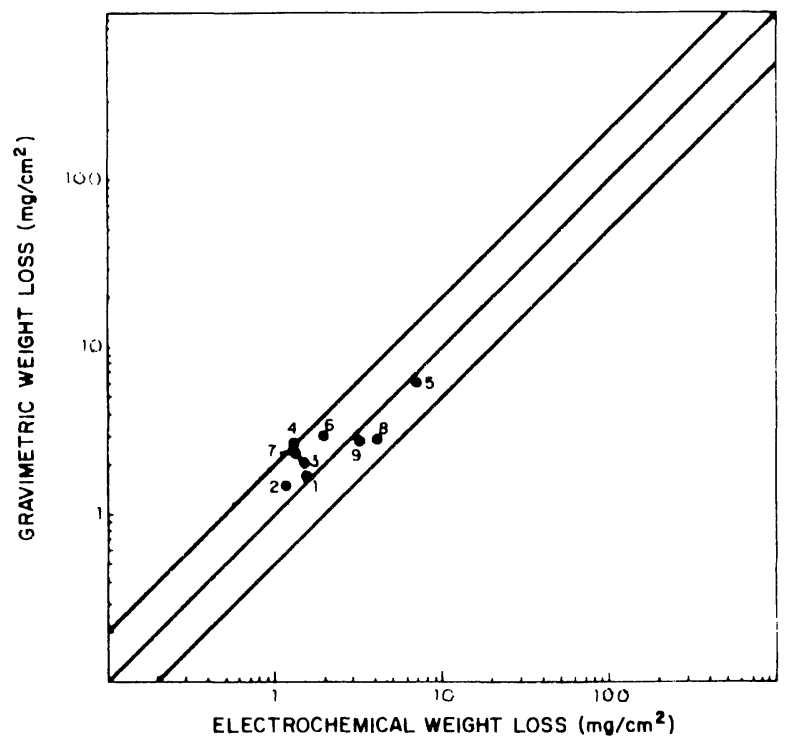

Fig. 5.-Comparison between gravimetric and electrochemical weight loss of the galvanized bars. 
álcali puede comprobarse cómo ha tenido lugar una precipitación de $\mathrm{Ca}(\mathrm{OH})_{2}$ en el seno de la disolución y sobre la capa cristalina que tapiza el redondo, tal y como queda de manifiesto en las figuras $6 \mathrm{c}$ y d.

7 días después de la adición de álcali, los cristales rómbicos presentan una ligera disolución en los bordes (fig. 6e), no obstante, el recubrimiento permanece, en rasgos generales, prácticamente inalterado, aunque algunos cristales hayan sufrido una disolución más intensa (fig. 6f).
$\mathrm{Ca}(\mathrm{OH})_{2}$ can be observed on the calcium hydroxyzincate layer in figures $6 c$ and $d$.

Seven days after alkali addition the only alteration observed is a slight dissolution of the borders of the $\mathrm{Ca}\left[\mathrm{Zn}_{2}(\mathrm{OH})_{6}\right) \cdot 2 \mathrm{H}_{2} \mathrm{O}$ crystals as is shown in the figure 6 e. An example of some of the most altered crystals is presented in figure $6 \mathrm{f}$. The general aspect of the calcium hydroxyzincate layer is that it remains compact and continous.

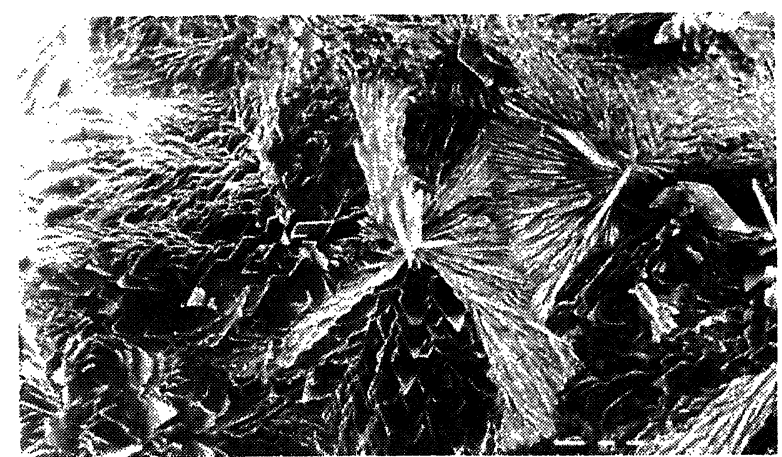

(a)

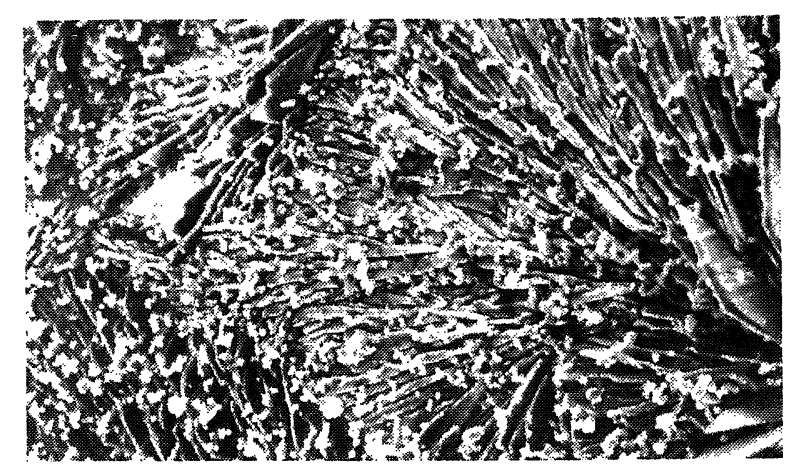

(c)

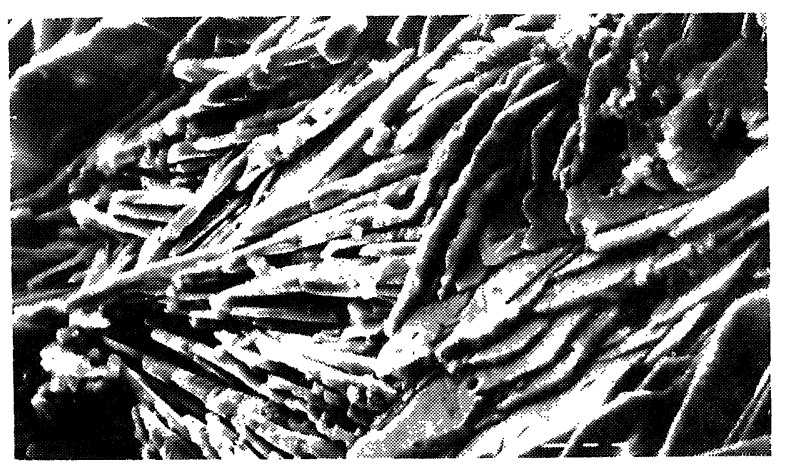

(e)

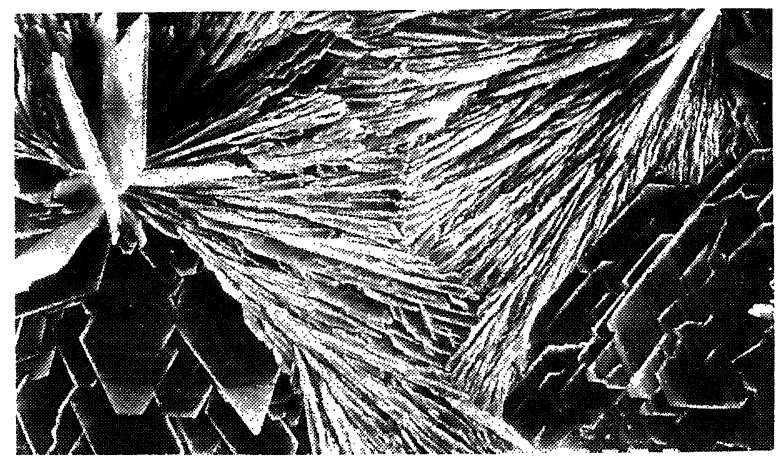

(b)

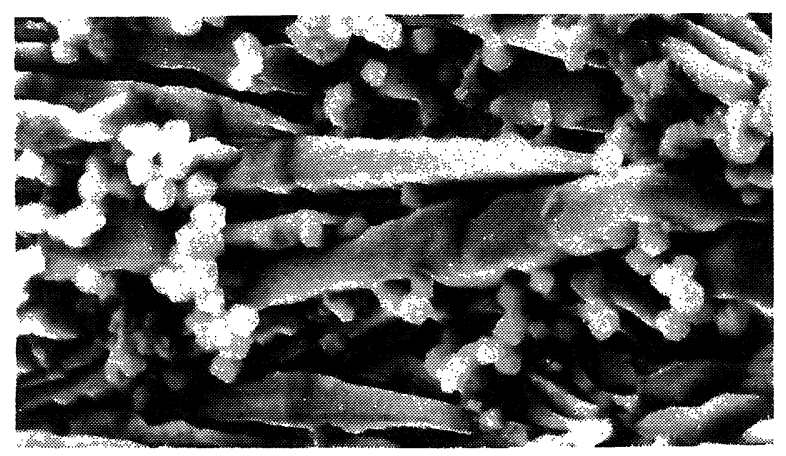

(d)

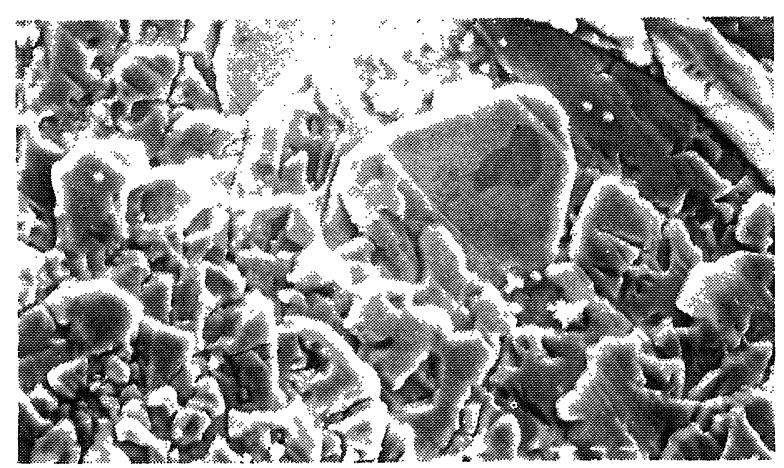

(f)

Fig. 6.-Corrosion products of galvanized rebars immersed in solution [Ca(OH) 2 sat] $28 \mathrm{~d}+0,5 \mathrm{M} \mathrm{KOH}(\mathrm{a}) \mathrm{before} \mathrm{KOH}$ addition (28 d) $\times 54$ (b) before $\mathrm{KOH}$ addition (28) $\times 160$ (c) $1 \mathrm{~h}$ after $\mathrm{KOH}$ addition $\times 200$ (d) $1 \mathrm{~h}$ after $\mathrm{KOH}$ addition $\times 1130$ (e) 7 days after $\mathrm{KOH}$ addition $\times 500$ (f) 7 days after $\mathrm{KOH}$ addition $\times 510$. 


\section{DISCUSION}

La naturaleza protectora del recubrimiento de hidroxizincato cálcico no se ve significativamente modificada si tiene lugar un aumento posterior a su formación del $\mathrm{pH}$ del medio, incluso en el caso de que la adición de álcali efectuada sea importante. El ataque observado en dicho recubrimiento por tal adición, se reduce a los bordes de los cristales, recobrando el redondo los valores de intensidad de corrosión que exhibia antes de la adición de álcali en un corto espacio de tiempo. El incremento de $i_{\text {corr }}$ detectado tras la adición de álcali es interpretado como fruto de la disolución anódica del metal en los huecos y defectos de la capa protectora de hidroxizincato cálcico. Si la concentración de álcali añadida es tal que sólo provoca un pequeño incremento del valor del $\mathrm{pH}$ de la disolución, la alteración que produce en la $i_{\text {corr }}$ puede ser considerada como despreciable. Por lo tanto, se puede deducir que un aumento gradual en el valor del $\mathrm{pH}$ en la disolución acuosa intersticial que rellena los poros del hormigón será menos agresiva que un abrupto cambio. Como ya ha sido mencionado (9), el valor del $\mathrm{pH}$ de la pasta de cemento, mortero u hormigón inmediatamente después del amasado debe ser inferior a 13,3 ya que la solución contiene iones sulfato. Los resultados aquí presentados sugieren que para obtener una pasivación estable del acero galvanizado, lo más importante es el desarrollo de una capa continua de hidroxizincato cálcico a edades tempranas, ya que un posterior aumento en el valor del $\mathrm{pH}$ no alterará el estado de pasividad de las armaduras sustancialmente. Por tanto, resulta favorable desde el punto de vista de la pasivación de las armaduras galvanizadas que los sulfatos reaccionen lentamente y tarden el mayor tiempo posible en desaparecer de la disolución. Un dramático aumento del valor del $\mathrm{pH}$, causado por una rápida reacción de los sulfatos con los aluminatos, antes de que la capa de hidroxizincato cálcico se haya formado conduciría a un mal comportamiento a largo plazo del galvanizado. Es asimismo favorable que la concentración del ion $\mathrm{Ca}^{2+}$ a edades tempranas sea elevada.

\section{CONCLUSIONES}

1. a) Después de que la capa pasivante del hidroxizincato cálcico está completamente formada, un aumento posterior del valor del $\mathrm{pH}$ de la disolución debido a una adición de $\mathrm{NaOH}$ ó $\mathrm{KOH}$ no afecta a su estabilidad. Tan sólo una ligera disolución química y un aumento transitorio de la intensidad de corrosión han sido observados, pero la capa permanece sustancialmente inalterada.

\section{DISCUSSION}

Even if very high amounts of alkalies are added, after the layer of calcium hydroxyzincate is formed, the protective nature of the layer is not significatively modified. The attack observed is only in the borders of the crystals and the corrosion intensities reach again the same values than before the alkali addition.

The increase of $i_{\text {corr }}$ detected after alkali addition is interpreted to be due to the dissolution of the base metal through the holes and lacks in the protective layer of calcium hydroxyzincate. If the alkali addition provokes only a small increase in the $\mathrm{pH}$ value, the alteration of the $i_{\text {corr }}$ can be considered as negligible. Therefore, it can be deduced that a gradual increase in the $\mathrm{pH}$ value in the pore concrete solution will be less aggressive than an abrupt one.

As it was mentioned (9) the $\mathrm{pH}$ value of the cement paste, mortar or concrete just after mixing should be lesser than 13,3 because the solution contains sulfate ions. The results presented here suggest that in order to obtain a stable passivation of the galvanized steel, the most important point is to develop during these early ages a continous and compact layer of calcium hydroxyzincate, because a further increase of the $\mathrm{pH}$ value will not alter the passivity. Therefore it is favourable for the passivation of the galvanized that the sulfates react slowly and take a longtime to disappear from the solution. A dramatic rise of the $\mathrm{pH}$ value, because a fast reaction fo the sulfates with the aluminates, before the layer of calcium hydroxyzincate is completely formed will lead in a bad perfomance at long term of the galvanized. It is also favourable that the concentration of $\mathrm{Ca}^{2+}$ ion during the early ages was high.

\section{CONCLUSION}

1. ) Afther the calcium hydroxyzincate layer is completely formed, a further increase of the $\mathrm{pH}$ value of the solution due to the addition of $\mathrm{KOH}$ or $\mathrm{NaOH}$ do not affect its stability. Only a slight chemical dissolution and a transitory increase in the corrosion intensity were observed, but the layer remain unaltered. 
2. $\left.{ }^{2}\right)$ El período más importante para asegurar el buen comportamiento del acero galvanizado a largo plazo en medios que simulan la disolución intersticial de los poros del hormigón, es el inmediatamente posterior al amasado. En este periodo inicial, la capa de hidroxizincato cálcico debe formarse y la disolución necesita contener cantidad suficiente de ion $\mathrm{Ca}^{2+}$ y un $\mathrm{pH}$ por debajo del valor umbral de 13,3. Por lo tanto, los iones sulfato deben permanecer en la disolución el mayor tiempo posible para asegurar estas dos condiciones.
2.) The most important period in order to obtain a good perfomance of the galvanized steel at long term in media which simulate the pore concrete solution, is just after mixing. During the early ages, the calcium hydroxyzincate layer must be formed and the solution needs to have high amounts of $\mathrm{Ca}^{2+}$ ions and to maintain the $\mathrm{pH}$ value below the threshold of 13,3. Therefore the sulfates ions must remain in solution as long as possible to assure these two conditions.

\section{BIBLIOGRAFIA}

(1) MACIAS, A. and ANDRADE, C.: Br. Corros. J., 1983, Vol. 18, No. 2, 82-87.

(2) BLANCO, M. T., ANDRADE, C. and MACIAS, A.: Br. Corros. J., 1984, Vol. 19, No. 1, 41-48.

(3) MACIAS, A. and ANDRADE, C.: Accepted by British Corrosion Journal.

(4) MACIAS, A. and ANDRADE, C.: Accepted by British Corrosion Journal.

(5) MACIAS, A. and ANDRADE, C.: Accepted by British Corrosion Journal.

(6) LONGUET, P., BURGLEN, L. and Zelwer, A.: Rev. Mat. Constr. n.॰ 676, January 1973 (1).

(7) LONGUET, P.: Silicates Industriels, 1976 - 7/8 (321-328).

(8) ANDRADE, C. and GONZALEZ, J. A.: Werkstoffe Korros., 1978, 29, 515.

(9) STERN, M. and GEARY, A. L.: J. Electrochem. Soc., 1975, 104, 56.

(10) MORAGUeS, A., MACIAS, A. and ANDRADE, C.: Accepted by Cement and Concrete Research.

\section{publicación del i.e.t.c.c.}

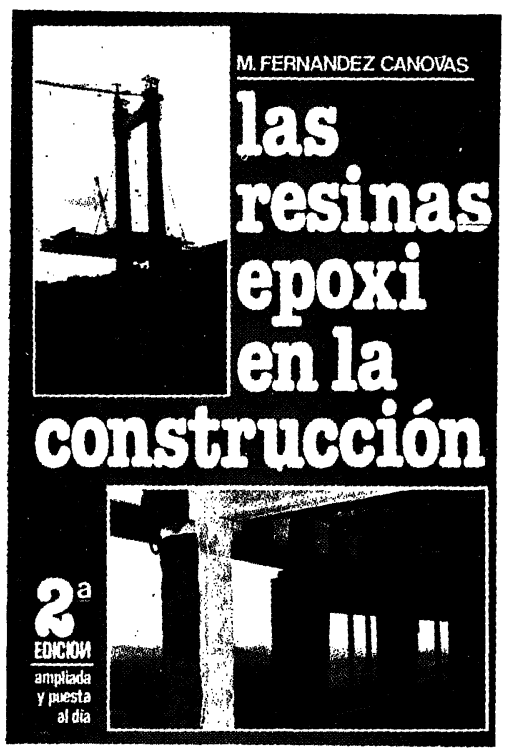

28
Manuel Fernández Cánovas

Dr. Ingeniero de Construcción

Este libro, el primero en lengua castellana sobre resinas epoxi aplicadas a la construcción, está dirigido a arquitectos, ingenieros, constructores y aplicadores. En él, sobre una reducida base teórica imprescindible, se asienta toda una extensa gama de aplicaciones de gran interés.

El autor trabaja desde hace muchos años en el campo de la investigación, especialmente en el estudio de refuerzos y reparaciones estructurales realizados con resinas epoxi.

Con un lenguaje sencillo se tocan todos los problemas que pueden presentarse en la construcción y en los que la solución puede radicar en el correcto empleo de las resinas epoxi.

Se estudian los componentes de las formulaciones epoxi, sus propiedades fisicas y quimicas, y aplicaciones, deteniéndose, detalladamente, en las siguientes:

Unión de hormigón fresco a hormigón endurecido. - Unión de hormigones entre si.--Inyecciones de fisuras y grietas... Unión de acero a hormigón. - Barnices y pinturas. - Las combinaciones brea epoxi. - Revestimientos de depositos alimenticios. - Sellado de superficies ceramicas.--Proteccion de tubos. - Los suelos epoxi en sus diferentes variantes. . Terrazo epoxi. - Reparación de baches. - Reparación de desperfectos en estructuras. … Reparación de carreteras de hormigón. - Juntas elásticas. Guardacantos de tableros de puentes.-Refuerzos de pilares, vigas, forjados y zapatas, etc. Consolidación de suelos. - Anclajes. - Protección de aceros en pretensado.

Se termina con unos capitulos dedicados a la limpieza y preparación de las superficies según los materiales a unir: al control del estado superficial de éstos; a las condiciones de temperatura de aplicación; limpieza de los útiles de trabajo; precauciones en el manejo de los sistemas; almacenaje, mezcla y manejo de las formulaciones epoxi métodos de ensayo de sistemas y aplicaciones epoxidicas.

Un volumen encuadernado en cartoné plastificado con lomo de tela, de $17 \times 24 \mathrm{~cm}$, compuesto de 334 páginas y 158 figuras y fotografias.

Madrid, 1981.

Precios: España, 1.700 ptas.; extranjero, \$ USA 34.00

MATERIALES DE CONSTRUCCION. Vol. 36, n.0 204, octubre/noviembre/diciembre 1986 